\title{
Lifestyles and the city: connecting daily life to urbanity
}

\author{
Albertine M. L. van Diepen · Sako Musterd
}

Received: 10 March 2008/Accepted: 20 April 2009/Published online: 22 May 2009

(C) The Author(s) 2009. This article is published with open access at Springerlink.com

\begin{abstract}
Urban households are part of what makes a city a city: economically, because of their labour market participation and use of urban facilities; and socially, because of their participation in public life. In turn, these urban households profit from what the city has to offer. In this paper, a household typology is constructed according to type and extent of 'urban connectedness'. Urban connectedness is not identified as people's stated preference but rather as people's revealed relationship with the urban society through their residential choices. Subsequently, the urban orientation of these household types is explored. Empirical data are obtained for the city of Amsterdam.
\end{abstract}

Keywords Households $\cdot$ Lifestyle $\cdot$ Urbanity $\cdot$ Urban life

\section{Introduction}

Everyday life in cities is distinct from everyday life elsewhere. Slogans such as 'the Toronto lifestyle' and 'the 'Cosmopolitan lifestyle' underline the particular way of life that is connected to cities. Older debates also make it clear that outspoken ideas about urban life can be opposed to, for example, suburban or country life (cf. Gans 1967, 1968; Wirth 1938). The urban aspect of life generally stands for such characteristics as 'expressive', 'outgoing', 'culturally prone', 'active', 'multiple', 'tolerant', 'consumptive', 'public' or 'deliberate'. What is unusual about this phraseology is the primary identification with the 'urban'. At the same time, urban life is multifaceted. A large variety of expressions of taste, speech, outlook, manner and sense are noticeable in cities. Due to the attainment of critical masses in cities, different lifestyles, embedded in various social networks, can emerge and flourish (Fishman 1994; Maffesoli 1996; Clarke 2003). As Zukin (1998) states, lifestyles

A. M. L. van Diepen ( $₫)$. S. Musterd

Amsterdam Institute for Metropolitan and International Development Studies, University

of Amsterdam, Nieuwe Prinsengracht 130, 1018 VZ Amsterdam, The Netherlands

e-mail: a.m.1.vandiepen@uva.nl

S. Musterd

e-mail: s.musterd@uva.nl 
are what cities do best. In this understanding of lifestyles, the concept of urbanity gains renewed attention. Many politicians and city planners perceive the liveliness and vitality due to occurrences of people and businesses in a central district as a pull factor to the city and as a means to prevent urban decay. However, a question rarely addressed remains what the meanings of urbanity actually are, and how urbanity is linked to the urban residents.

Understood as expressions of taste and preferences, lifestyles are associated with consumers' freedom of choice and transience. However, the formative structures underlying them are not. Much of the daily life observed in urban areas is not about expressions of private preferences, but is deeply rooted in home and work routines, such as going to work, doing the laundry, having dinner and getting some sleep; activities that have to fit into a 24-h scheme (Hägerstrand 1982). This paper builds upon these underlying social and economic characteristics that structure everyday life in the city. Therefore, urban social structures, reflected by residential patterns, are not interpreted as products of choice or preferences, but as products that are highly affected by social and economic constraints to urban life. We understand lifestyle as behaviour related to household types, with regard to housing, use of urban facilities and orientation on the city. As such, we employ a broader concept than the often employed smaller notion of lifestyle that is based on taste and preference.

Many academics have taken an interest in empirically linking urbanity to lifestyles. At least two approaches can be distinguished (Van Diepen and Arnoldus 2003). First, some scholars-predominantly sociologists - consider lifestyle to be an effect of the characteristics of the urban environment. Wirth, for instance, in his famous article 'Urbanism as a way of life' (1938), relates urban lifestyles to the number of inhabitants, high density and heterogeneity of cities. He finds that social relationships in cities are highly formalized and fragmented, which leads to anonymity. Zukin (1998) and Clarke (2003) understand the variety of lifestyles in cities from the social and economic diversity present in the urban environment. And more generally, Sobel (1981) and Bourdieu (1984) attribute specificities in manner and taste to urban-regional distinctions and characteristics of space. A second approach, largely employed by social geographers, regards the urban-regional distribution of household types as a result of household formation and behavioural practices. The point of departure is everyday life and the conditioning impact of the physical-spatial environment. Bell (1968), for instance, departs from the assumption that households with a particular 'familism' lifestyle will try to move to the suburbs because this fits their needs best.

In this paper we join the geographic approach and scrutinise the linkages between household structures and urbanity. We assume that the level of urbanity and the presence of non-urban and urban-connected households are mutually related. On the one hand, urbanity pulls certain people into its area, as they might benefit from the amenities and opportunities, such as the presence of a wide variety of economic activities and services, the proximity and accessibility of public or semi-public places, and opportunities for faceto-face contact. On the other hand, urban dwellers - and some types in particular-contribute to the articulation and the accomplishment of a city's economy and its social vibrancies. In such a perspective, cities and their dwellers are both reliant on, and necessary assets for, each other. To answer the question regarding the linkages between urbanity and urban residents, we attempt to associate the various indicators of both the level of urbanity and household characteristics that structure everyday life in the city to gain insight into their two-sided relationship. The paper starts with some theoretical observations about social and economic characteristics that structure everyday life and generate, as such, the human geography of cities. This leads to the presentation of a 
typology of households according to urban connectedness. The third section gives a brief discussion of some of the literature on urbanity to identify levels of urbanity. In the remainder, we present and relate data for levels of urbanity and for household types according to urban connectedness - data available for the city of Amsterdam, The Netherlands - to identify the degree and meaning of the assumed mutual relationship between urbanity and urban residents.

\section{Urban life}

Throughout the past four decades, household life in western societies has become more diverse and temporary. Under the influence of mutually interacting social and economic developments, household structure today is characterized by a pluralization and fluidization of households' lifestyles (Buzar et al. 2005). Processes of ageing and of more relaxed social norms and the patterns of partnership and living arrangements associated with the second demographic transition all account for an increased complexity of transitions between different household structures: people's lives are longer but less predictable in terms of how individual paths develop through household careers. For instance, more and more people live alone for at least part of their life course, whether after leaving the parental home, after a divorce, or because of widowhood. The household-level change is occurring against a background of the 'post-Fordist' flexibilization of the economy and employment. The 'one-breadwinner per family' model has been replaced by household arrangements in which often both adults participate in the labour market. Both those social and economic processes are not place-indifferent, but rather resulted in a geographic sorting and concentration of household types.

More so than other kind of settlements, cities comprise a wide-ranging mix of household arrangements and livelihoods. Although urban residence can be pursued for a variety of reasons, the strong embeddedness of certain household types in the city is a consequence of the organization of everyday life and daily activity patterns (Jarvis et al. 2001; Karsten 2007). Urban residence provides households with, among other things, ample availability of facilities and services and the opportunity to minimize the coupling constraints on performing various daily tasks and recurring activities. Obviously, residence within the urban area makes commuting less time consuming, grocery shopping easily feasible, and options for outsourcing accessible. For that reason, for some household types, urban life is the preferred option. For example, young single or two-person households whose orientation is outside the home may find what they want in the city. However, urban residence is, for some household types in particular, not per se just a matter of preference due to the attractiveness or aesthetics of cities, or simply because of the possibility to engage in all kind of adventures that cities offer. To put it in Bourdieu's terminology, notwithstanding the urban experience and urban symbolism, largely the functionality of cities draws and connects people to its territory. Urban housing and residence can be a fundamental condition to live the life that emanates from major decisions in life regarding household and family formation and the acquisition of income (Karsten 2007). In particular, when household arrangements are getting more complex, efficiency can be expected from the time-geographic benefits of urban residence. Or, the other way around, because urban housing and residence are intertwined with other domains in life, for Karsten (2007) it rather represents 'a way of life'. It is in this perspective that Buzar et al. (2005) refer to the household as an urban agent. 
Due to the process of continual formation and reformation of household arrangements, supplemented by selective migration of particular household types, relatively small households dominate the urban core whereas the larger and all-encompassing households are prevalent at the urban outskirts. For the city of Paris, France, Ogden and Schnoebelen (2005) find that adults, many of whom live alone and are often highly qualified for the labour market, opt to reside in very urban locations. These households have become dominant on the urban housing market as their working careers provide access to houses at the upper end of the market. However, they signal a considerable dispersion of such small, professionalized households to the wider region. Also in Amsterdam, The Netherlands, more than half of all households consist of just one person. Due to the wide variety of affordable housing - even in the city centre-the high representation of one-person households in the city is also a manifestation of people being unemployed or being at school and does not coincide with the occupational structure so strictly. Adult couples are also well represented in the urban core. There are also indications that some, perhaps even an increasing number of, middle-class households with children settle in urban environments, but serious evidence for this association is rather thin so far (see Butler and Robson 2003; Karsten 2007).

The urban constellation, thus, gives rise to the assumption that the household distribution is a reflection of the type (economic and/or social) and the extent (small or large) of the urban connectedness of those households. Based on the analysis of structural household attributes-i.e. age, household composition, and labour market participation-households can be classified into five categories (Fig. 1). Households classified as 'economically urban' are particularly involved in urban society due to their high labour market participation. Urban residence is beneficial for them because of the proximity and accessibility to a large variety of jobs or the transit connections with other working areas. By contrast, households classified as 'socially urban' are particularly involved in urban society due to the social advantages that the city offers, that is, the ample opportunities to contact, meet or

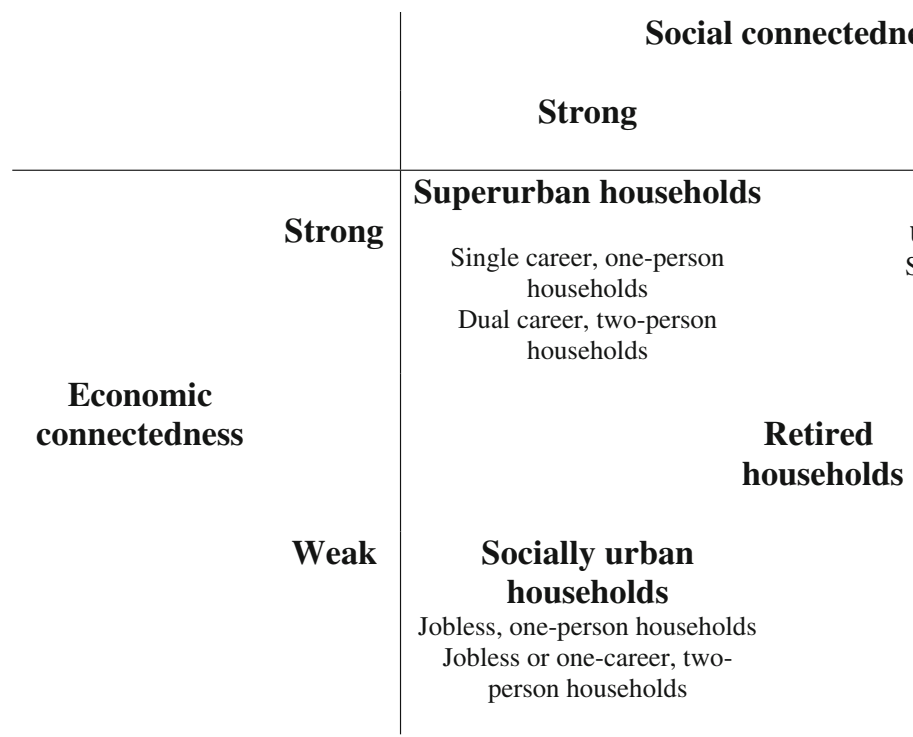

Weak

\section{Economically urban households \\ Single career, one-parent households \\ Dual career, family \\ households}

Fig. 1 Household types according to type and degree of urban connectedness

\section{Non-urban} households

Jobless, one-parent family households Jobless or one-career, family households 
simply be in the vicinity of people of all types. Furthermore, those households that are classified as 'super urban' are characterized by both an economic and a social involvement in the city, whereas households classified as 'non-urban' are not. Of course, they might be interested in urban life, but their household arrangements in terms of age, household composition and paid work do not induce urban settlement. Finally, retired households comprise a separate category. By reaching the age of 65 , the household enters a next stage both in the family life cycle (children have left the parental home) and regarding the labour market (retirement). Because of the loss of economic engagement and social necessities out of the home, the retired households tend to induce an inward orientation towards the home and the daily environment. However, their type and degree of urban connectedness is rather inconclusive yet and we place this household type in between.

Based on the formative household attributes of age, household composition and labour participation, household types are assumed to reflect a certain type and degree of urban connectedness. As these attributes change over time, urban connectedness is transitory too.

\section{Urbanity}

Usually, urbanity refers to centrally located city sites where urban values such as solidarity, tolerance and the enjoyment of differences can exist. It is in the pragmatic, daily practices of a city's pubs and restaurants, streets and shops, that 'pictures of a functioning urbanity' come into being (Latham 1999). The association between these values and urbanity trace back to the multiple uses of such semi-public and public places and domains by different groups for different activities and behavioural expressions (Hajer and Reijndorp 2001). Physical-spatial characteristics are also often pointed at when speaking of urbanity, varying from a high-density and fine-grain design, to the implant of landmarks and the application of visual stimulation and attention to detail that may produce multiple uses and urban values. According to the urban designer Montgomery (1998), the physical-spatial or builtup environment is a necessary but in itself insufficient condition for urbanity. 'Without activity there can be no urbanity' (Montgomery 1998, p. 96).

During the 1960s and 1970s, the link between urbanity and the city centre started to weaken and the concept of urbanity lost its significance. Urbanity no longer seemed restricted to central cities, as social diversity, mixed public culture and new forms of economic activity could also be found elsewhere (cf. Fishman 1994). In addition, some mega-cities emerged that lacked traditional indicators of urbanity, such as lively public domains and a high-density, fine-grained mix of different land uses in its central parts. Moreover, some historical city centres, as in Detroit and Los Angeles, suffered heavily from decay and social disruption and the people avoided rather than invested in those bleak districts.

However, urbanity is presently regaining attention from urban politicians and planners. They have recently been supporting and heralding the cities' variety and vibrancy as an ideal means to achieve urban economic and social vitality. Not only practitioners and professionals report the potential of urbanity to attract people and businesses to the city. The fine mix of public, semi-public and private domains in the city is found to be important for urban-economic and for urban-social functions (cf. Zukin 1998). Florida (2002) draws on similar conventions about urbanity, contending that certain characteristics of cities guarantee urban success. He finds that a city's attractiveness for economic activity increases the more the city is characterized by cultural diversity, openness and tolerance. Helbrecht (2004) also stresses these soft conditions when she argues that nowadays cities 
have to show they have an attractive residential environment, tolerance of alternative lifestyles, a lively cultural scene, a good 'look' and 'feel' and adequate-preferably public_-meeting places for business and leisure.

\section{Data and method of analysis}

To determine the degree of association between indicators of level of urbanity and presence of non-urban and urban household types, the analysis is based on three data sources. First, for the city of Amsterdam, we used a survey conducted by the Municipality of Amsterdam in 2003, which included 3,442 people. This dataset provided information about the structural household characteristics, the geographical attributes of residence, as well as some urbanity indicators. Second, we used data from the Dutch Housing Demand Survey 2002, conducted by the Ministry of Housing, Physical Planning and Environmental Management. This survey, including over 66,400 people in the net response, provided geographical information about residence but did not contain detailed information about urbanity. For both the Amsterdam and the Dutch national sample, we transformed the data from an adult persons file to a household file. This implied the use of a weight factor (per household category and geographical district) to avoid over-representation of, for instance, large households. Third, we used a municipal data register containing very detailed information about the housing stock (available on six-digit postal code level) and about employment in firms (distinction based on a detailed five-digit firm code).

The first step in the analysis is to determine the presence of the distinguished urban types of households, economically and/or socially. In this exploratory stage, we compare Amsterdam with The Netherlands as a whole. The second part of the analysis concerns the geographic distribution of the various household types in the city of Amsterdam to scrutinize the extent to which urban-connected households are indeed residing in the more urbanized districts in the city. Finally, the third step concerns the search for associations of urban households with-expressions of - the level of urbanity, both univariate and multivariate. Do those households that are more connected to the urban setting actually express a more urban orientation? The level of urbanity is represented by two sets of variables; one set measures behavioural performance at the individual level, whereas the other set indicates characteristics of the residential environment.

At the individual level, urbanity is revealed by three distinct performances. These indicate the use of urban facilities by households. First, urbanity is expressed by visits to cultural events. Out of ten optional events, this variable specifies the extent to which people actually participate in urban cultural life. We assume that higher levels of participation in urban cultural life indicate higher urban connectedness. Second, the degree of outsourcing of housekeeping activities is considered to support outgoingness, and we therefore, assume this is an expression of urbanity. This variable measures the presence of one or more of six domestic devices such as a microwave or dishwasher. Third, urbanity is expressed by the degree of social encounters outside the home, represented by three variables: the degree to which people contact friends, family and people in the neighbourhood, expressed on a rating scale from 1 (no contact) to 5 (at least weekly contact). It is assumed that urbanconnected households meet more often with local people and less with family and friends compared to not urban-connected and retired households.

Also at the geographical level, several variables are indicative of urbanity: the distance to the city centre; the housing stock mix; the employment mix; and the participation of fulltime employees in public and semi-public meeting places such as hotels, restaurants, bars, 
cafés and pubs. Distance to the city centre represents the distance from the centroid of the household residence's six-digit code to the centroid of Dam Square. The housing mix variables, indicating the degree of homogeneity of the housing stock with regard to homeownership and property value, is a dichotomous variable; ' 0 ' means homogeneous (the housing stock in the six-digit postal code zone comprises at least $75 \%$ of only one type) and ' 1 ' indicates a mixed housing stock. For the functional mix variable, we selected grid cells that have a relatively high number of different firm codes. We applied the criterion that at least ten different codes should be present in a grid cell (corresponding to a level of two standard deviations above the mean number of different codes in a grid cell). Adjacent grid cells that meet the criterion were merged into a larger area. For the variable of labour participation in hotels, restaurants, cafes and pubs, we only show areas with at least 50 people working there and where at least $15 \%$ of those employed work in these sectors (a similar two standard deviations criterion).

\section{Results}

For 2003, the Amsterdam population can indeed be typified as urban, as about threequarters of the households are urban according to at least one of the two distinguished dimensions. Of all households in Amsterdam, 38\% can be described as super urban. Households that are economically urban in character account for $15 \%$ of the households. The share of households that are socially urban in character is $21 \%$. Those households that are urban for neither economic nor social reasons make up $10 \%$ of the households. Retired households represent $16 \%$ of the households.

Some striking observations were made when we compared the Amsterdam household distribution according to degree of urban connectedness with that for Dutch households in general (Fig. 2). First, looking at the diagonal 'strong-strong' to 'weak-weak' urban

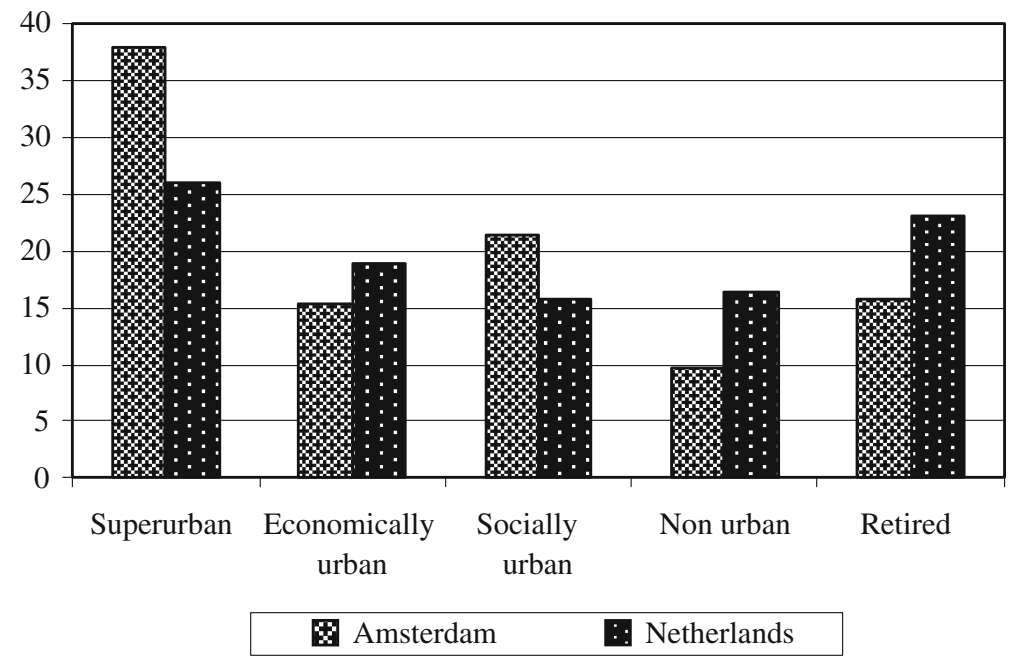

Fig. 2 Household distribution according to household types in Amsterdam (2003) and in the Netherlands (2002). Source: Department of Research and Statistics, Municipality of Amsterdam (2003) and Ministry of Housing, Physical Planning \& Environmental Management, Dutch Housing Demand Survey (2002) (authors' calculation) 
Fig. 3 a Distribution of the super urban household type in Amsterdam (2003). b Distribution of the economically urban household type in Amsterdam (2003). c Distribution of the socially urban household type in Amsterdam (2003). d Distribution of the non-urban household type in Amsterdam (2003). e Distribution of the retired household type in Amsterdam (2003)

connectedness as projected in Fig. 1, the Amsterdam household population tends to have a more urban profile than the average Dutch household population. As expected, in Amsterdam the super urban households are considerably over-represented, whereas nonurban households are quite under-represented compared to the Dutch average. Secondly, also the socially urban households are very much over-represented in the city, which is in line with the traditional social support function of the city and, for that matter, with the large social housing stock. Perhaps more surprising is that the economically urban households are less well represented in Amsterdam than they are in The Netherlands at large. Despite the benefits of living in well-connected urban districts, it appears that households with a large stake in the labour market often leave Amsterdam. Regarding retired households, Fig. 2 shows that Amsterdam has relatively fewer retired households compared to The Netherlands as a whole.

Let us look more closely at the distribution of household types across the urban area. Where do the various household types live? From the Fig. 3a-e it appears that those households that we consider to be the most urban-tied in character do indeed live in the most urbanized parts of the city. Figure 3a-e show the patterns for each household category. The construction of the classification starts with the household category 'average'. Cut-off points are selected at $10 \%$ and $25 \%$, above and below the average. The overall patterns are statistically significant. Super urban households (Fig. 3a) are over-represented and dominant, both relatively and absolutely, in the centrally located districts, the city centre and the adjacent 19th-century districts. Households that are economically connected to the city are less strongly represented in the municipality as a whole. Only three districts have a strong representation of this economically urban household category, namely the post-war neighbourhoods in the west and in the southeast of the city. Figure $3 \mathrm{~b}$ also shows that 'pure' economically urban households, whose adult members have a job or a career, are found near highway access points, but are hardly present in the centrally located and old parts of the city itself. The same applies to the households that are characterized as nonurban households (Fig. 3d). Compared to the other household categories distinguished here, they form a rather small category in Amsterdam. Family households are most often found at the urban outskirts or in the more spacious dwellings built in the post-war period. Households that are connected to the city for mainly social reasons are rather evenly distributed over the city. These socially urban households are the least over-represented or under-represented in the various districts (Fig. 3c). Households consisting of retired people (Fig. 3e), on the contrary, are hardly present in the centrally located, old districts, while they are over-represented in the more peripheral districts.

Is there any empirical basis for stating that urban-embedded lives are conducive to urbanity? Is urban connectedness, socially and/or economically, also related to various levels of urbanity? Table 1 indicates the relationships between households according to urban connectedness and level of urbanity for ten indicators. Except for mixed housing by property value, all urbanity variables show significant differences for the various household types. The graphs allow for an analysis of two steps. First, a dichotomy according to degree of urbanity is discerned. Second, urbanity itself is further partitioned into super urban and socially urban versus economically urban. 

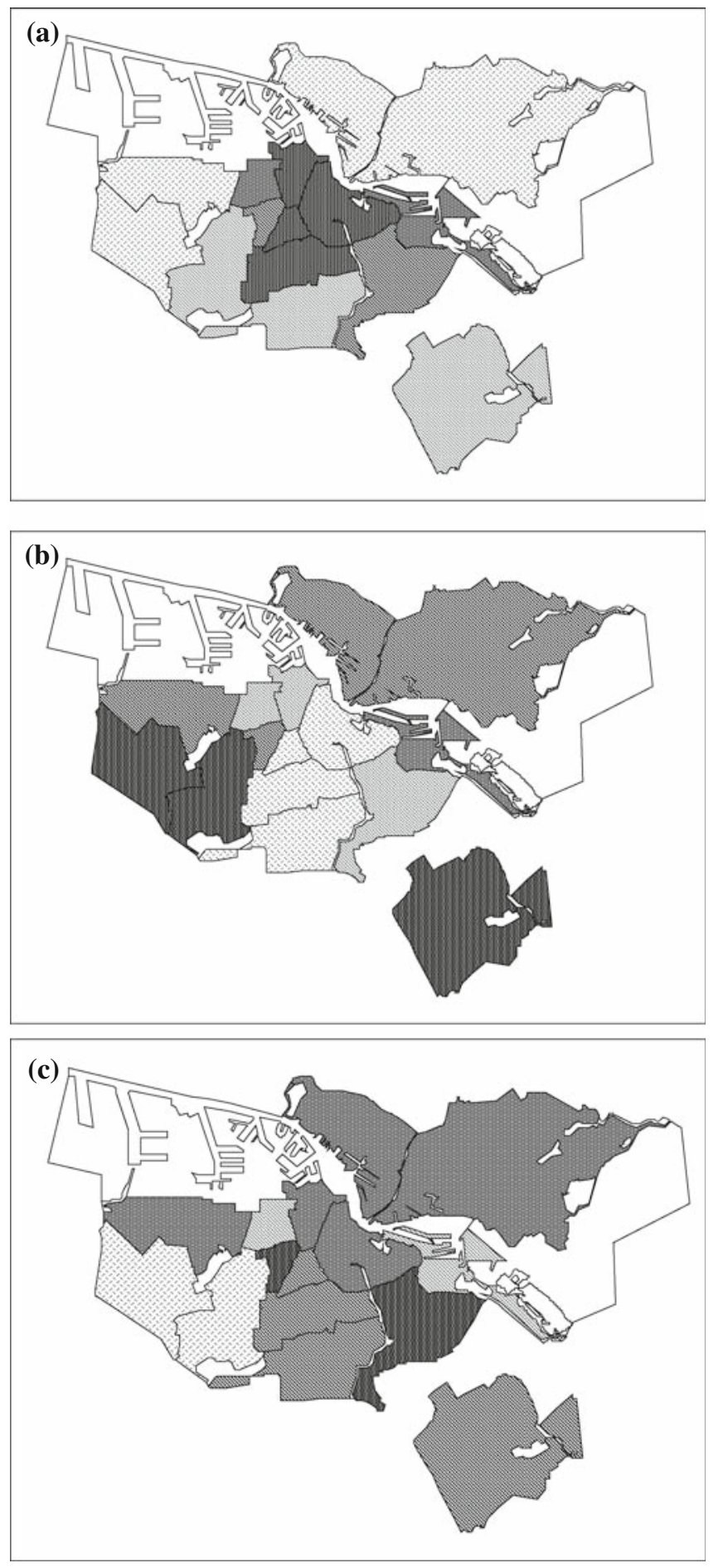

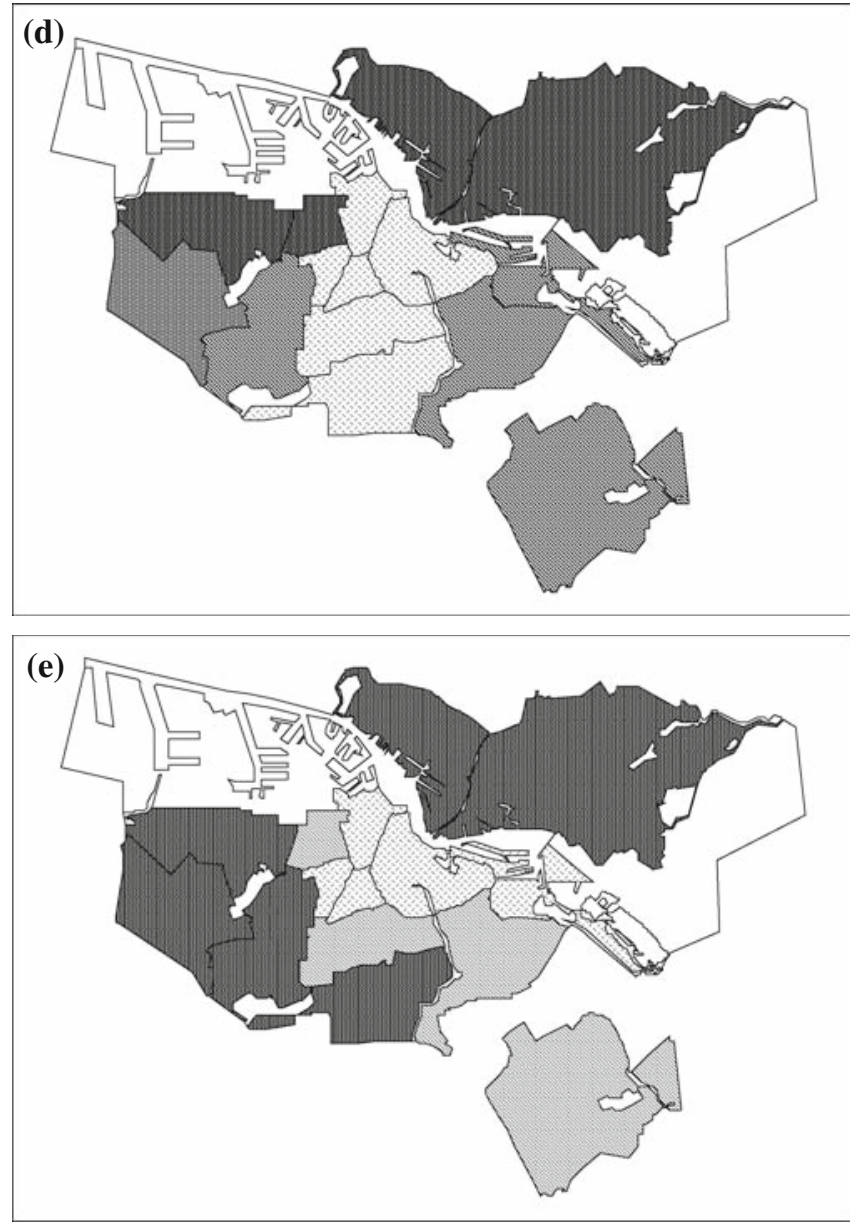

\section{Strong over-representation \\ Substantial over-representation \\ Average score \\ Substantial under-representation \\ Strong under-representation}

Fig. 3 continued

Four of the ten indicators of levels of urbanity show a dichotomy between the urban households on the one hand and the non-urban and retired households on the other. With regard to cultural life, the level of urbanity is for the urban households-i.e. the super urban, the economically urban, and socially urban types-remarkably higher than for the non-urban and retired households. In particular, the super urban households have a large stake in a city's cultural life. Furthermore, urban households live significantly more often in mixed districts with respect to homeownership compared to the non-urban households. In particular, the super urban and socially urban households seem to be more often housed in a mixed area than the economically urban households. Contacts with family and with 


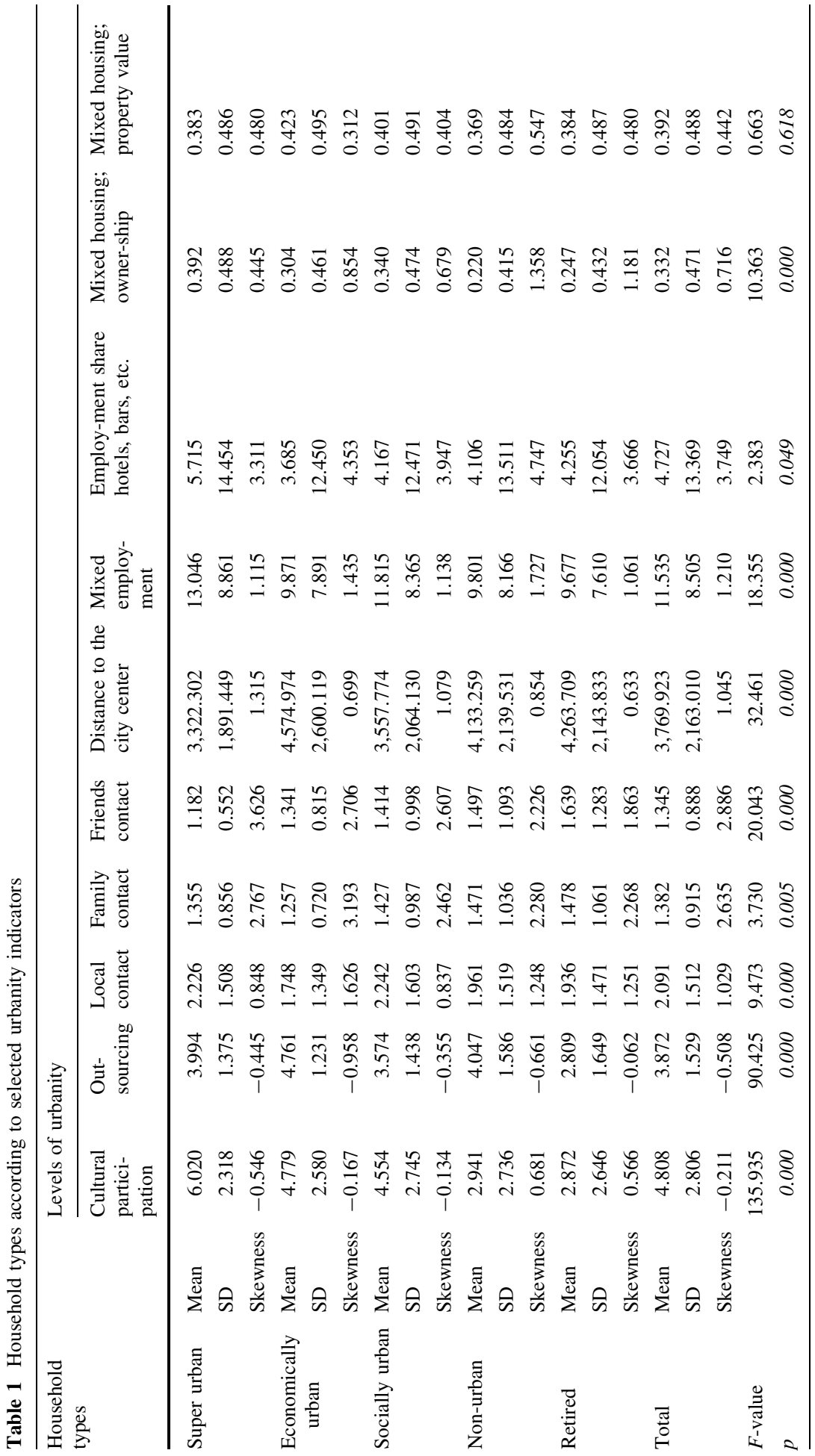


friends show a proportionally inverse relationship to urbanity. The non-urban and the retired households contact their family and their friends most often and significantly more often than the urban household types do. Remarkable and rather unexpected is the low score on family contact for economically urban households. Because of their family formation and full labour market participation, these households were expected to rely on the family. A possible explanation of their low score is their general tendency to outsource, which might also include day care for their children instead of reliance on the family. Both contacts with family and with friends, however, are variables with a rather skewed distribution.

Five urbanity indicators identify a further distinction between the super urban and socially urban households on the one hand and economically urban households on the other. Outsourcing appears to be more related to available time budgets rather than to the level of urbanity itself. Economically urban households most often have various household appliances at their disposal. Probably the large amount of time spent on both paid work and family matters necessitate such timesaving household facilities. In contrast, and as expected, the socially urban and the retired households, which participate neither in the labour market nor in family life, show the lowest rates of outsourcing. Having a significant responsibility either for paid work or for family matters, respectively, super urban and nonurban households show moderate levels of outsourcing. A distinction between super urban and socially urban households and economically urban households is further observed in the level of contact with local people. As expected, super urban and socially urban households have much more frequent contact with local people outside the household compared to other household types. Economically urban households show a significantly low rate of local contact, which could be attributed to their small amount of free time. Other indicators of urbanity, but measured at a more aggregate (i.e. territorial) level, are distance to the city centre, employment share of jobs in hotels, bars, and restaurants, and the mixed employment level. Again, both super urban and socially urban households show a significantly stronger orientation toward urbanity compared to family-based households as well as retired households. They live more often in central districts with a diverse employment and a clearer presence of hotels, bars, and restaurants.

Employing a principal component analysis summarizes and extracts the essential information from the eight hardly skewed variables into three meaningful components (Table 2). The first component stands for the social-cultural orientation, as it is particularly related to a short distance to the city centre, a highly functional mix, a heterogeneous

Table 2 Component matrix of principal component analysis (varimax)

\begin{tabular}{lccc}
\hline & $\begin{array}{l}\text { Social-cultural } \\
\text { orientation }\end{array}$ & $\begin{array}{l}\text { Economic-cultural } \\
\text { orientation }\end{array}$ & $\begin{array}{l}\text { Public-local } \\
\text { orientation }\end{array}$ \\
\hline Cultural participation & 0.458 & 0.574 & -0.159 \\
Outsourcing & -0.206 & 0.868 & 0.096 \\
Local contact & -0.188 & -0.226 & 0.681 \\
Distance to the city center & -0.785 & 0.145 & -0.078 \\
Mixed labour force & 0.740 & -0.019 & 0.212 \\
Share hotels, bars, etc. in labour & 0.226 & 0.147 & 0.646 \\
$\quad$ force & 0.556 & 0.116 & 0.064 \\
Mixed housing; owner-ship & 0.206 & 0.035 & 0.400 \\
Mixed housing; property value & & & \\
\hline
\end{tabular}


housing stock, and an extensive cultural life. The second component represents the economic-cultural orientation, which is determined predominantly by outsourcing and cultural life. The third component could be regarded as a dimension of public-local orientation. Major signifiers of this 'place-based' component are contact with local people and the ample availability of semi-public and public meeting places. Together, the three components explain $52 \%$ of the total variance.

To what extent do the three components produce significantly different patterns for the five household types? The patterns support the suggestion that there is indeed a firm relationship between household types and urbanity (see Fig. 4). Regarding the socialcultural dimension, the super urban and socially urban households resemble each other (i.e.

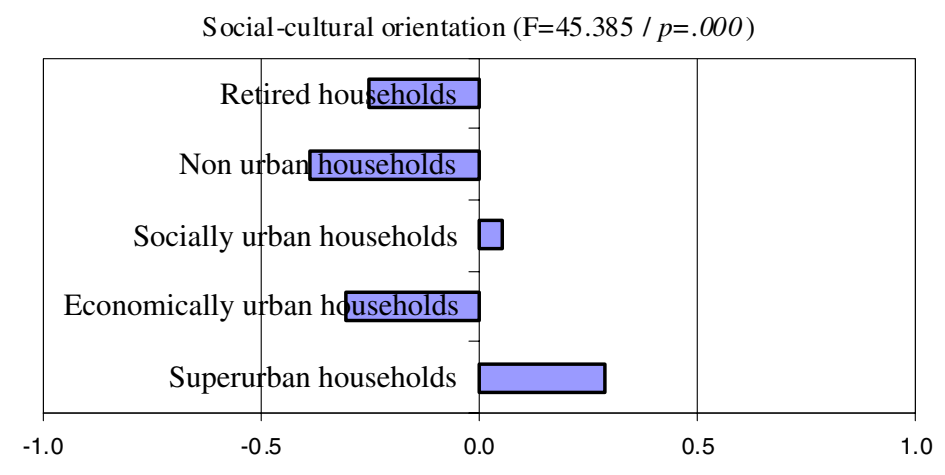

Economic-cultural orientation $(\mathrm{F}=115.875 / p=.000)$

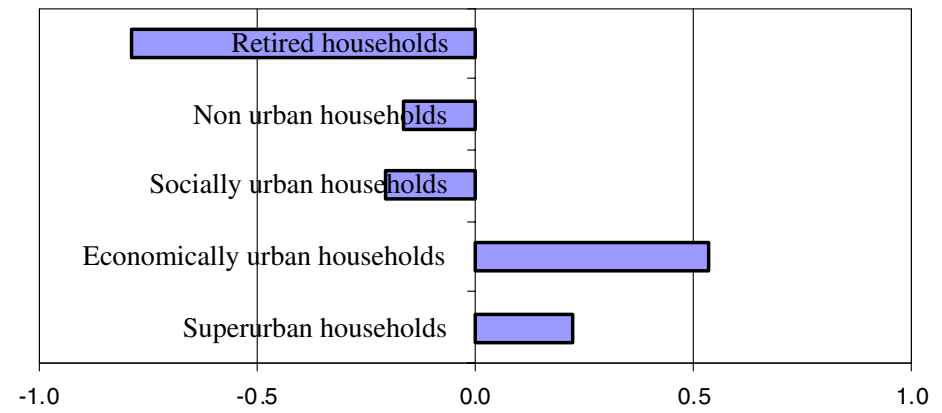

Public-local orientation $(\mathrm{F}=1.766 / p=.133)$

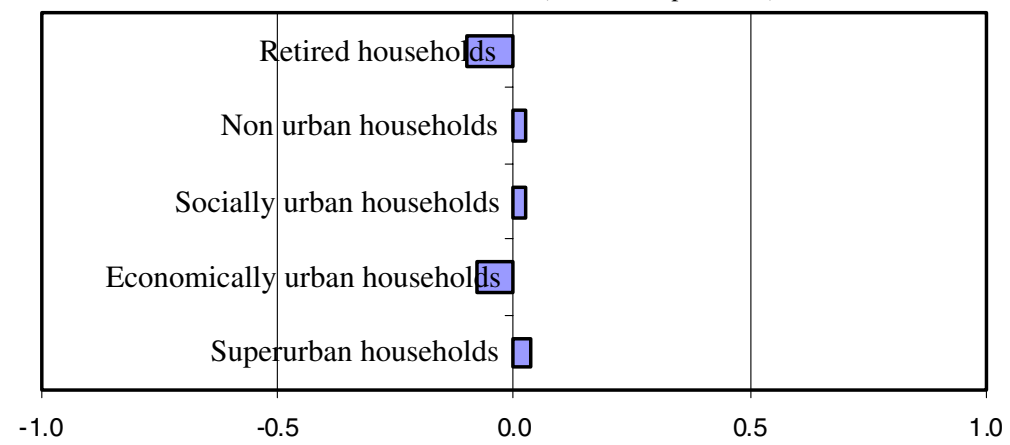

Fig. 4 Average scores of urban and non-urban household types on three urbanity components 
they have a positive average score) when compared to the other three household types. The economic-cultural dimension is especially distinctive - generating a positive average - for super urban and economically urban households, as compared to others. The public-local dimension is not significantly related to the extent and degree of urban disposition of households.

\section{Conclusions}

Household structure and urbanity are indisputably related to each other. While allowing that there might be other important reasons why people could be linked to the urban daily environment, this paper has pointed out the mutual interests that a vital urban society and certain households share. Of course, the household population in the city of Amsterdam is predominantly urban in character. In turn, these urban households add to the urbanity of Amsterdam, as their utilization of urban functions, in either social or economic terms, also implies a contribution to the city's drive and dynamism. Furthermore, the Amsterdam spatial patterns of the household categories show the concentration of urban-connected household categories in the more centrally located districts and the non-urban household category on the outskirts of the city.

We have to keep in mind, however, that internal household dynamics (e.g. becoming older or unemployed, or becoming a parent) will imply transitions between household categories and therefore influence the city's function for the household. The household might experience pressure on its changed position regarding its urban connectedness. Particularly the transition from the super urban to the economically urban category, when a couple starts a family, needs further attention. It is precisely this household type that has difficulty in finding suitable residence in a city like Amsterdam. Their high labour market participation as well as their potential claim on various household services outside the home are at odds with their imminent desire for larger dwellings and protected neighbourhoods. Such residential environments are rare in the city. Policy strategies aimed at keeping these households in the city should be considered; for example, policy might target the supply and/or improvement of safe residential environments for children and the improvement of the multiple use of public space. To retain households for the city that become less urban-connected when members of the household lose their job, it is important to open up the residential market regionally. The match between housing supply and demand in the regional context requires permanent attention. That should be accompanied by continuous efforts to understand the mutual relationship between urbanity and the urban connectedness of various household types.

Open Access This article is distributed under the terms of the Creative Commons Attribution Noncommercial License which permits any noncommercial use, distribution, and reproduction in any medium, provided the original author(s) and source are credited.

\section{References}

Bell, W. (1968). The city, the suburb and a theory of social choice. In S. Greer (Ed.), The new urbanization (pp. 132-168). New York: Putnam Books.

Bourdieu, P. (1984). Distinction. Cambridge: Harvard University Press.

Butler, T., \& Robson, B. (2003). London calling, the middle classes and the re-making of inner London. Oxford: Berg. 
Buzar, S., Ogden, P. E., \& Hall, R. (2005). Households matter: The quiet demography of urban transformation. Progress in Human Geography, 29, 413-436.

Clarke, D. B. (2003). The consumer society and the postmodern city. London: Routledge.

Fishman, R. (1994). Urbanity and suburbanity: Rethinking the 'Burbs'. American Quarterly, 46, 35-39.

Florida, R. (2002). The rise of the creative class and how it's transforming work, leisure, community and everyday life. New York: Basic Books.

Gans, H. (1967). The Levittowners. London: Allen Lane.

Gans, H. J. (1968). Urbanism and suburbanism as ways of life: A re-evaluation of definitions. In R. E. Pahl (Ed.), Readings in urban sociology (pp. 95-118). Oxford: Pergamon Press.

Hägerstrand, T. (1982). Diorama, path and project. Tijdschrift voor Economische en Sociale Geografie, 73, 323-339.

Hajer, M., \& Reijndorp, A. (2001). In search of a new public domain. Rotterdam: Nai Uitgevers.

Helbrecht, I. (2004). Bare geographies in knowledge societies—creative cities as text and piece of art: Two eyes, one vision. Built Environment, 30, 194-203.

Jarvis, H., Pratt, A., \& Wu, P. (2001). The secret life of cities, the social reproduction of everyday life. Harlow: Pearson Education Ltd.

Karsten, L. (2007). Housing as a way of life: Towards an understanding of middle-class families' preference for an urban residential location. Housing Studies, 22, 83-98.

Latham, A. (1999). Powers of engagement: On being engaged, being indifferent and urban life. Area, 31, $161-168$.

Maffesoli, M. (1996). The time of the tribes: The decline of individualism in mass society. London: Sage.

Montgomery, J. (1998). Making a city: Urbanity, vitality and urban design. Journal of Urban Design, 1, 93116.

Ogden, P. E., \& Schnoebelen, F. (2005). The rise of the small household: Demographic change and household structure in Paris. Population, Space and Place, 11, 251-268.

Sobel, M. (1981). Lifestyle and social structure: Concepts, definitions, analysis. New York: Academic Press.

Van Diepen, A. M. L., \& Arnoldus, M. (2003). Housing demand in a demand-driven context. Amsterdam: DGW/Nethur partnership.

Wirth, L. (1938). Urbanism as a way of life. American Journal of Sociology, 44, 1-24.

Zukin, S. (1998). Urban lifestyles: Diversity and standardisation in spaces of consumption. Urban Studies, $35,825-839$. 